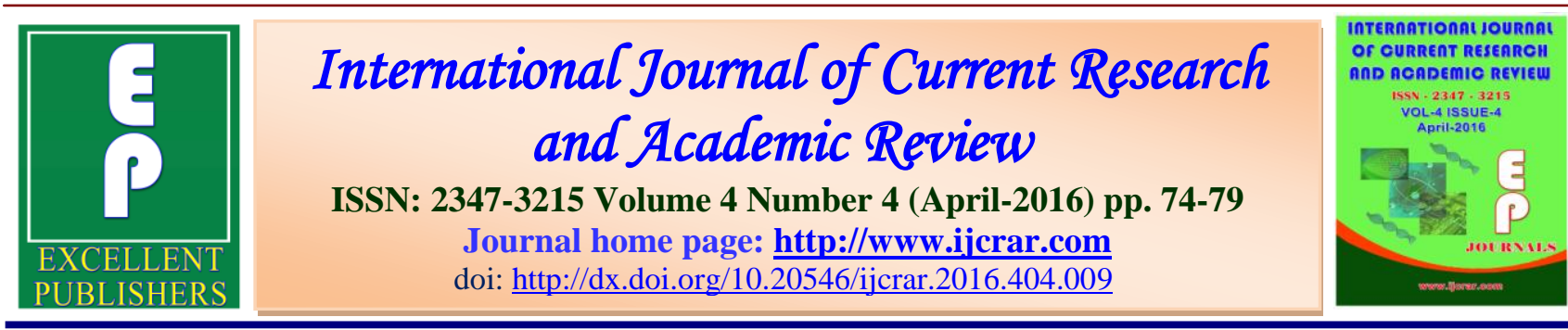

\title{
The Philosophical Base of Advaita Vedanta and its Relevance to Present Day Students
}

\author{
K.S. Sivakumar ${ }^{1 *}$ and A.S. Viswanathan ${ }^{2}$ \\ ${ }^{1}$ Department of Sanskrit and Indian Culture, SCSVMV University, Enathur, Kanchipuram, \\ India \\ ${ }^{2}$ Department of Electrical and Electronics Engineering, SCSVMV University, Enathur, \\ Kanchipuram, India
}

*Corresponding author

\section{KEYWORDS}

Advaita Vedanta, Epistemology, Ethics, Metaphysics, Comprehensive learning model.

\section{A B $\mathbf{S}$ T $\mathbf{R}$ A $\mathbf{C}$ T}

A philosophical system is generally classified under three important facets, namely, epistemology, metaphysics and ethics. An attempt is made in this paper to expound the above facets of Advaita Vedanta and discern its relevance to present day students. The epistemology of Advaita Vedanta states that scriptures (or) revelation (sruti) transmitted through the verbal testimony (sabda) of the Guru is the ultimate means of measurement (pramana) regarding the source and validity of knowledge. The present day students are offered an important understanding that even though there may be innumerable sources of acquiring information, teachers are still the foremost, primary and un-substitutable source for acquiring valid knowledge. The ethical structure of Advaita Vedanta is given by the standard; Purification of the mind (sattva (or) citta suddhi). Purification of the mind points to the influences in the doer"s frame of mind or the betterment of character. The present day students are offered an understanding that self-effort in the form of further reading, doubt clearance, etc., must be adopted in order to better understand the concepts imparted by teachers. Self-effort results in internalization of the acquired knowledge According to the metaphysics of Advaita Vedanta, Brahman alone is ultimately real and Is non-different from the essential and eternal nature of man (ie) atman. Knowledge of Brahman-atman is not an external acquization but an inner intuitive experience (anubhava). To know Brahman is to be It. Epistemology merges into metaphysics. Modern day students are offered an important learning that the culmination of knowledge lies in its practical application. Thus, we are able to clearly observe that the philosophical base of Advaita Vedanta enable the modern day students to understand that the process of acquiring valid knowledge is complete only when it passes through the three vital stages of (1) Acquiring knowledge from the teachers (2) Self-effort, leading to internalization of knowledge, by the students, and (3) Experiencing the practical application of knowledge by the students. 


\section{Introduction}

The etymological meaning of the word 'philosophy' is 'love of learning/knowledge'. It signifies a natural and a necessary urge in human beings to know themselves and the world in which they live. The structure of any philosophical system may be classified into three broad facets, depending on the subject-matter under consideration. The three broad facets are; (Sri Sankaracarya, 1995) Epistemology (Sri Sankaracarya, 1993) Metaphysics and (Chandogya Upanisad, 1996) Ethics. Epistemology deals with the theory of knowledge, its sources and its validity for man. Metaphysics explores the ultimate real nature of man. Ethics is concerned with the social and spiritual code of conduct of man.

\section{Indian Philosophical Tradition}

The 'Vedas' which means 'to know' as well as 'knowledge', are the oldest literary monument of the Indian Philosophical tradition. The Vedas consists of four portions, namely, the Mantras, the Brahmanas, the Aranyakas and the Upanisads. The Mantras consist of hymns addressed to various Gods and Goddesses.. The Brahmanas deals with the rules and regulation for the performance of rites and scarifies.The Aranyakas consists of the mystic interpretation of the vedic sacrifices. The Upanisads consists of doctrines about the highest Reality.

\section{Vedanta}

The Upanisads are popularly known as Vedanta. There are basically two reasons for it. First, the Upanisads are literally the concluding portion or the end of the Veda. Second, the Upanisads are the essence, the cream, the fountain-head of the Vedic philosophy.
There are three main interpretations of the Vedanta. They are Advaita Vedanta (Nondualism),

Vishistadvaita Vedanta (Qualified nondualism), and Dvaita Vedanta (Dualism)

\section{Advaita Vedanta}

Advaita Vedanta is one of the most complete and holistic system of Vedanta. Advaita teaches that Reality is beyond all dualities and It refers to the highest realization of the non-dual Oneness of all being, Sri Sankaracarya is considered as the greatest preceptor of the Advaita Vedantic tradition. He was the first to systematize and strengthen the philosophy of Advaita. Sri Sankara, in his Brahmajnanavalimala ${ }^{1}$ presents the basic tenents of Advaita Vedanta as under;

\section{Brahma satyam jagan mithya}

Jivo brahmaiva naprah

(Brahman is the Reality. The world is illusory. The embodied soul is indeed Brahman and not essentially different from It.)

\section{Epistemology of Advaita Vedanta}

In the Indian epistemological system, the source of knowledge and the means of measuring its validity is referred to as Pramana. It is a means of discovering new truth as well as a means of verifying knowledge.

Advaita Vedanta recognizes six kinds of valid knowledge (pramana). They are ;

(1) Perception (pratyaksa) (2) inference (anumana) (3) Verbal testimony (sabda) (4) Comparison (upamana) (5) Postulation (arthapatti) and (6) non-apprehension (anupalabdhi) 
The Importance of Verbal Testimony (sabda)

According to Advaita Vedanta, Verbal testimony is the only Pramana which can communicate the facts of sense-universe as well as the supra-sensible truths. Suprasensible truths are contained in the scriptures (sruti (or) veda). In his commentary on the Brahma-sutra, Sri Sankara States that sruti is the only source of revelation regarding the knowledge of non-dual Brahman.

Advaita also maintains that the contents of the sruti is transmitted only through the verbal testimony (sabda) of the guru. The Chandogya Upanisad states that "only a man having a teacher acquires knowledge" (Acaryavan purusah veda). In his Vivekacudamani, Sri Sankara points out that discipleship under an enlightened teacher is one of the three rarest fortunes achieved by man through God's grace.

Thus, we observe the importance accorded to the verbal testimony of the guru, in the epistemological domain of Advaita Vedanta.

\section{Implications of Advaita Epistemology for the Present Day Students}

With the rapid growth and development of Information technology and communication links, modern day students have a number of sources to acquire information and knowledge. Moreover, all these information can be gathered at the convenience of the students. In such an environment, the role and effectiveness of a teacher, in a class room condition, comes into sharp focus.

It is this context that the epistemology of Advaita Vedanta enable the modern day students to understand the fact that even though there may be innumerable sources of acquiring information, teachers are still the foremost and primary source of acquiring valid knowledge. It is often said that only a lighted lamp can lit another lamp. Bulbs and tube lights cannot perform the task. All other sources of knowledge may compliment a teacher but can never substitute a teacher. Thus, we see the importance of teachers reaffirmed by the epistemology of Advaita Vedanta.

\section{Ethics of Advaita Vedanta}

In the system of Advaita Vedanta, the ethical standard is given by; Purification of the mind (citta (or) sattva suddhi), by which moral judgements are effected. In his commentary on the Brhadaranyaka Upanisad, Sri Sankara points out that actions are performed as a means to the purification of the mind and only a purified mind can easily know the Self, that is revealed by the Upanisads. This means that the goodness or rightness of any action is determined by the degree of cittasuddhi it promotes. Since Karmayoga (wherein, actions are performed without attachment to the rewards and as worship to God) promotes Cittasuddhi, actions performed as Karmayoga are considered as good actions in the ethical system of Advaita Vedanta.

\section{Undertanding Citta (or) Sattva Suddhi}

Every action, in addition to its own objective result, influences the character of the doer also. It produces in the mind of the doer a tendency (samskara) for similar action. A bad action creates a tendency know as durita. A good action cultivates a counter tendency known as citta suddhi to remove durita. Thus, in the removal of durita or duritaksaya consists the purification of the mind. Citta suddhi refers to the influences in the doer's frame of mind or the betterment of character. 
The Bhagavad gita points out that our desires and dispositions, moods and temperaments, actions and tendencies, feelings and emotions, are all to be traced to the influence of the three gunas, namely, sattva, rajas and tamas of prakrti. No one is exempted from the influences of these gunas. The essential nature of sattva is serenity (prakasa), rajas is restlessness (pravrtti) and tamas is slothfulness (alasya). Even though sattva is very proximate to the essential nature of man, man is often influenced by rajas and tamas. The aim of moral training is to restore man to his sattiv nature by reducing the influence of the other two gunas. This process is indicated as sattva suddhi.

Thus, we are able to observe that citta (or) sattva suddhi refers to the betterment of character, the mental purification of man towards the objective of sattva, effected by successfully counteracting the evil tendencies (durita ksaya) prompted by rajas and tamas.

\section{Implications of Advaita Ethics for the Present Day Students}

In the modern day world, where information are readily and conveniently available, students merely gather information from different sources and tend to feel that they have mastered a topic or a subject. A few basic and searching questions on the subject would expose the students to the fact that they are indeed far from adequate knowledge on the subject or topic under consideration.

It is in this context that the ethics of Advaita Vedanta enable the modern day students to understand the fact that the acquired information and knowledge must be internalized through self-effort. Self-effort may take the form of further readings, arguments, dispel of doubt and wrong understanding, reasoning, etc. Self-effort, leading to internalization, enable the students to have a firm grasp, correct and logical understanding of the imparted knowledge.

Thus, we observe the importance of selfeffort for students underlined by the ethical perception of Advaita Vedanta.

\section{Metaphysics of Advaita Vedanta}

According to Advaita Vedanta, reality is explained as that whose nature remains uncontradicted (or) unsublated (traikalikabadhya) and ever real at all times (traikala satyam). In his commentary on the Brahmasutra, Sri Sankara states that Brahman is the only reality because It is never sublated by an higher experience. The Taittiriya Upanisad states that the knower of Brahman attains the highest. The Brhadaranyaka Upanisad points out that Brahman-knowledge is the supreme attainment, the supreme glory, the highest world and supreme bliss. The same Upanisad refer to Brahman as completeness (purna). Therefore, Brahman is the ultimate and highest reality (paramarthika satta).

\section{Understanding Brahman-atma anubhava}

Advaita Vedanta maintains that Brahman, the eternal objective Self, is synonymous with atman, the inner subjective Self of man. The Mandukya Upanisad states that "This atman is Brahman". The Brhadaranyaka Upanisad states "I am Brahman". The Chandogya Upanisad 13 states "Thou art That" (Tat Tvam Asi). Thus, Advaita advocates the complete identity of Brahman-atman.

According to Advaita Vedanta, Brahmanatman is not an external acquization but an inner intuitive realization (anubhava). Anubhava may be understood as the 
intuitive experience of the ultimate truth (Brahman). Sri Sankara, in his commentary on the Brahmasutra states that the knowledge of Brahman must culminate in the direct realization (anubhava) of Brahman. It refers to the realization of Oneself as Brahman (brahmatmabhava). As the Mundaka Upanisad states "One who knows Brahman becomes Brahman". To know Brahman is to be It. Thus, in the system of Advaita Vedanta, we observe that epistemology merges into metaphysics.

\section{Implications of Advaita Metaphysics for the Present Day Students}

Most of the students are of the opinion that acquiring knowledge is predominately a theoretical pursuit with little practical dimension. Even if students are exposed to practical, they perceive it as an extension to knowledge and perform it as a ritual, without much enthusiasm, not knowing the value of practical knowledge.

It is in this context that the metaphysics of Advaita Vedanta enable the modern day students to understand the fact that the process of acquiring knowledge itself is not complete unless the knowledge is put to practical application. In fact, the experience of the practical application of knowledge is the culmination of the knowledge acquiring process. In other words, the fructification of the knowledge acquiring process lies in experiencing its practical applicability. Thus, we observe the importance of practical application of knowledge being affirmed by the metaphysics of Advaita Vedanta.

\section{Conclusion}

From the foregone discussion, we are able to clearly observe that the philosophical base of Advaita Vedanta provides vital learning for the present day students. The epistemology of Advaita Vedanta points out the essential and primary source of acquiring valid knowledge - the teachers. The ethics of Advaita Vedanta underlines the important role played by self-effort in internalizing the acquired knowledge. The metaphysics of Advaita Vedanta provides the much-needed completeness to the knowledge acquiring process-experiencing the practical applicability of knowledge.

\section{Comprehensive Learning Method for the Students}

Advaita Vedanta provides the students with a comprehensive learning method to acquire valid knowledge. The learning process can be presented in the form of three important steps (or) stages.

Step/Stage I Acquiring basic and primary knowledge about the subject from the teachers.

Step/Stage II Putting in Self-effort by the students to internalize the acquired knowledge.

Step/Stage III Experiencing the practical application of knowledge by the students.

The process of acquiring valid knowledge would be complete only when all the three stages are successively attained by the students. Let us hope that the knowledge thus acquired would convert itself, in the fullness of time, as wisdom for the students.

\section{References}

1. Sri Sankaracarya. 1995. Brahmajnanavalimala (verse 20), as quoted by Dr.S.Sankaranarayan in Sri Sankara-His life, Philosophy and Relevance to Man in Modern Times, The 
Adyar Library and Research Centre, Madras, p.156.

2. Sri Sankaracarya. 1993. Brahma-sutra Bhasya (II: i.27 and II: iii.1), translated by Swami Gambhiranada, Advaita Ashrama, Clacutta, pp.354 and 445.

3. Chandogya Upanisad. 1997. (VI.14.2) with the commentary of Sankaracarya, translated by Swami Gambhiranada, Advaita Ashrama, Calcutta, p.488.

4. Sri Sankaracarya, Vivekacudamani. 1998. (verse 3), translated by Swami Turiyananda, Sri Ramakrishna Math, Madras, p.2.

5. Sri Sankaracarya's commentary on the Brhadaranyaka Upanisad (IV. iv,22), translated by Swami Madhavananda, Advaita Ashrama, Clacutta, 1997, p.524.

6. Bhagavad gita. 1993. (XIV. 5 and 17) with the commentary of Sri Sankaracarya, translated by Dr.A.G.Krishna Warrier, Sri Ramakrishna Math, Madras, pp.472 and 480.

7. Sri Sankaracarya, Brahma-sutra Bhasya (II.i.14), p.331.
8. Taittiriya Upanisad. 1996. (II.i.1) with commentary of Sri Sankaracarya, in Eight Upanisads, Volume One, translated by Swami Gambhiranada, Advaita Ashrama, Clacutta, 1996, p.304.

9. Brhadaranyaka Upanisad. (IV. iii, 32), p.475.

10. Ibid., (V. I.1), p. 556.

11. Mandukya Upanisad. 1998. (II) with commentary of Sri Sankaracarya, in Eight Upanisads, Volume Two, translated by Swami Gambhiranada, Advaita Ashrama, Clacutta, p.175.

12. Brhadaranyaka Upanisad. (I. iv, 10), p. 100

13. Chandogya Upanisad (VI.8.7), p.468

14. Sri Sankaracarya, Brahma-sutra Bhasya (I: i.1), p.11.

15. Mundakya Upanisad. 1998. (III.ii.9) with commentary of Sri Sankaracarya, in Eight Upanisads, Volume Two, translated by Swami Gambhiranada, Advaita Ashrama, Calcutta, p.163.

\section{How to cite this article:}

Sivakumar, K.S., and Viswanathan, A.S. 2016. The Philosophical Base of Advaita Vedanta and its Relevance to Present Day Students. Int.J.Curr.Res.Aca.Rev.4(4): 74-79. doi: http://dx.doi.org/10.20546/ijcrar.2016.404.009 